\title{
Nautical tourism
}

\author{
J. Kasum ${ }^{1}$, J. Žanić Mikuličić ${ }^{2} \&$ K. Božić Fredotović ${ }^{3}$ \\ ${ }^{1}$ Hydrographic Institute of the Republic of Croatia, Split, Croatia \\ ${ }^{2}$ Tourist Board of Municipality of Podstrana, Podstrana, Croatia \\ ${ }^{3}$ Ministry of the Sea, Transport and Infrastructure, Zagreb, Croatia
}

\begin{abstract}
This paper notes and emphasises the importance of developing a relatively new nautical market. Nautical market is defined as a system and subsystems are divided into offshore and on shore technical and technological systems. The connectivity within the nautical market system and the environment is determined. The US and EU marines are clearly specified. On the noticeable growing nautical market, various factors have different impact. Therefore, correlation and the impact of various factors such as safety of navigation, education, protection, environmental impact and optimal control in the economic activities of nautical tourism are systematically described in this paper.
\end{abstract}

Keywords: nautical market, system, navigation safety, management, marina.

\section{Introduction}

According to [1] the following we cite: "Nautical tourism is an increasingly popular way to combine love of sailing and boating with vacation and holiday activities. First defined as an industry segment in Europe and South America, it has since caught on in the United States and the Pacific. Not only is nautical tourism an enjoyable way to see unique parts of the world, it is also a very profitable industry. Many tourists who enjoy sailing combine water travel with other activities. Supplying the equipment and accessories for those activities has spawned businesses for those purposes. With many nautical enthusiasts living on board their vessels even in port, nautical tourists bring demand for a variety of goods and services. Marinas developed especially for nautical tourists have been built in Europe, South America and Australia." With the aim of defining the 
nautical market, the starting point should be based on fundamental economic definitions:

- the market,

- supply,

- demand,

- consumers and

- profit.

Generally speaking, the market is the intersecting point or place of supply and demand. Economic supply is defined to be the quantity of a particular goods at a particular manufacturing price. The consumer is defined to be a person purchasing products and/or services created from another industrial or economic system.

The aim of successful marketing is definitely to achieve profit. It is defined to be a clear gain, earnings or a positive difference between invested and achieved. According to the fundamental definitions, the following terms should be defined:

- maritime nautics in nautical tourism,

- nautical market,

- nautical supply,

- nautical demand,

- nautical consumer and

- profit achieved on the nautical market.

Maritime nautics is defined to be the art of managing any kind of boat from the departure point to the arrival point. With the aim of developing a definition of nautical tourism, nautics in nautical tourism is defined to be the skill of running an unconventional vessel from the departure point to the arrival point.

The nautical market is defined to be the intersecting point or location of the supply and demand of goods and/or services in nautical tourism.

Nautical supply is defined to be quantity of a particular good or goods at a particular manufacturing price on the nautical market.

Nautical demand is defined to be the quantity of a good or goods that nautical enthusiasts on the nautical market want to make a purchase according to particular prices that are valid on the nautical market.

Profit achieved on the nautical market is defined to be the gain, earnings or a positive difference in invested and achieved.

\section{The nautical market system}

The general model of nautical tourism determines the fundamental subsystems and fundamental schemes within the system and environment.

Subsystems of the nautical market system relate to off-shore and on-shore technical and technological systems. An off-shore subsystem includes all the technical-technological systems on the water and/or sea in the function of the nautical market. Generally, vessels according to the Convention on the 


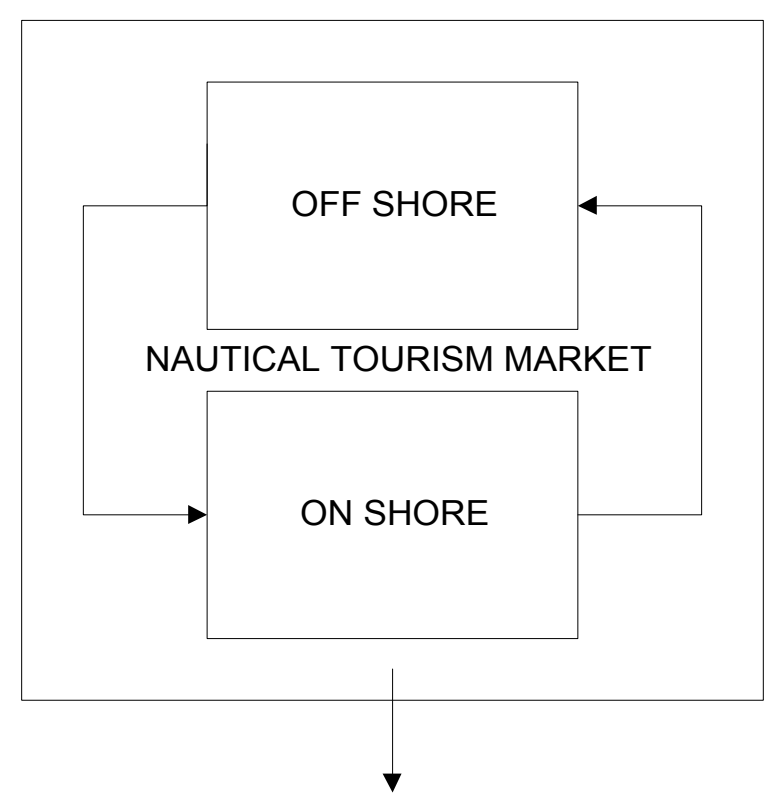

Figure 1: General model of the nautical market system.

Protection of Human Life at Sea (Safety of Life at Sea - SOLAS) are divided into conventional and unconventional.

Conventional vessels are defined to be vessels larger than 500 BT including passenger vessels. Unconventional boats refer to military and police boats, boats belonging to the government, war boats, fishing boats and boats of a primitive construction, as well as recreational boats. The off-shore subsystem of the nautical market system refers to unconventional vessels, i.e. recreational vessels such as yachts, sailing boats, speed boats, dinghies, rafts and other vessels.

The on-shore subsystem includes all technical-technological systems on land in the function of the nautical market. The on-shore subsystem of the nautical market system includes the subsystems: marinas, and their environment.

Marina as a type of nautical tourism port in the Italian sense of the word refers to a relatively small port essential for receiving and/or mooring recreational vessels. According to [4] The national Association of Engine and Boat Manufacturers Incorporated of America, a marina is defined to be a place appropriate for anchoring, casting off, repairing and supplying vessels and includes the opportunity to shower and obtain food supplies close to the shopping, communication and traffic infrastructure. Therefore, it may be proposed that the marina be defined as a nautical market subsystem for receiving and the harboring of unconventional boats with crews on the sea, rivers and lakes. It may operate independently or within a particular larger port intended for conventional boats and so on. According to the type of construction and level of equipment, we can distinguish types of marinas in the USA and EU. 
Marinas in the USA are distinguished by their relatively cheap, uniform and quality construction, as well as highly efficient business organisation. The infrastructural content of marinas in the USA are functional and varied.

EU types of marinas are not identical in terms of construction. They are relatively poorly equipped in terms of infrastructure. In comparison to marinas in the USA, they possess a smaller capacity in receiving the number of boats. A relatively frequent term is the so-called dry-dock. It is considered to be a landsite providing services for storing and/or keeping boats. According to the position ( $\lambda$ and $\rho$ ) of existing marinas and in terms of the area of the water way in various countries in the world, a classification for marinas is recommended as to whether they are on lakes, internal water ways, and the sea.

Marinas on lakes can, in terms of safety, for example, meteorological conditions be considered as relatively peaceful. The navigation area for boats on lake marinas is of course limited to size, i.e. the area of the lake and its eventual links to maritime routes for other vessels in the region and of course to vessels with boat characteristics.

Marinas on internal maritime routes, i.e. rivers and similar waterways are mostly in terms of size determined also by the dimensions of the river. The consequential maritime region for recreational boats is limited by the maritime capabilities of the river and of course the maritime characteristics of the boat.

Sea marinas are considered to be the most widespread and generally available forms of marinas. They are considered to be the largest when taking into account the possibilities of receiving particular boats and the size of boats. The maritime region for the boats is limited exclusively to their characteristics.

In analysing, for example, the plans and/or photographs of various marinas, it can be concluded that the constructions vary on the basis of natural features of land sections, freely constructed and combined marinas.

Therefore, with the familiar and defined nautical market, system, subsystem and contained links, it is possible to determine the region essential for optimal management of resources and divided into categories such as:

- maritime safety,

- education,

- protection,

- impact on the environment and

- optimal management.

Besides the other factors, a direct influence on the maritime security has also the maximum exactness of the information content in maritime maps and navigational publications of all types. Its occurrence precedes the standardised procedure of hydrographical organisation, i.e. hydrographical survey. It is used to gather information on the physical and chemical properties of the Earth. A hydrographical survey primarily refers to the gathering of data on water masses. Then, information is collected on: water depths, configuration and natural characteristic of the bed, the direction and speed of sea currents, times and heights of low and high tides and positions of solid objects important for navigation and surveying. Basic measurements in hydrographical surveys are depth measurements. In order to determine the submarine relief of the depth, it is 
necessary to conduct preparation of terrain works, compile a geodetic basis, equip the boat with devices, chose a method in navigating the hydrographical boat along the depth routes and continually determine its position. Therefore, in countries with developed nautical tourism special emphasis is placed on the essential implementation of the hydrographical survey within an appropriate category in areas linked to intensive maritime traffic by unconventional vessels in nautical tourism ports [3]. Also, it is important to educate persons who are involved in the nautical market subsystems. Therefore, the survey of the Republic of Croatia in the European Union can be taken as an example, which possesses developed nautical tourism activities.

As an example of good practice in education, emphasis should be placed on the program course at the Maritime Faculty, the University of Split, particularly the majors in maritime technology and yachts and marinas and maritime management [2]. In these programs, the content closely related to the nautical market is treated in a detailed manner. It provides students with an adequate quantity of knowledge and competency, while nautical tourism as a part of maritime economics becomes a good source of quality human resources.

When reflecting on protection and negative impacts, it is necessary to emphasise that the International Standards for Port Safety and Security Code (ISPS) is used as a rules system for Convention Vessels in world maritime seas, rivers and lakes. The Unconventional Vessels, which are categorised as boats used in nautical tourism also navigate in all world seas, rivers and lakes and use available nautical tourism ports. It is important to emphasise the existence of a real risk in the safety of unconventional vessels and nautical tourism ports due to the absence of similar rules relating to protection for this category of vessel and port $[5,7,9]$.

The impact on the environment in the area of nautical tourism may also be significant. In the nautical tourism ports, a whole series of activities is carried out by causally linking the impact of various forms of environmental pollution. Hence, for example, the impact on the environment in a nautical tourism port is carried out in three developmental phases which are: construction, usage and termination of its usage. Nautical tourism vessels have significant impact on the environment during the time of its mooring in nautical tourism ports and while navigating [8].

Since nautical tourism if relatively new, it is considered that, for example, in optimal management and strategic decision making on marinas, a variety of management decisions are brought about based on descriptions, calculations, existing economics, statistical and other indicators. An analysis of the marina business, e.g. in the Republic of Croatia, indicates that in decision making an inadequate number of exact indicators are utilised. From the aspect of the science of economics, it may be assumed justifiable to reduce the uncertainty in managing the business of a nautical tourism port by increasing the number of exact parameters. Its development and application would significantly reduce the unreliability in the management and thereby direct affecting an increase in profit [6]. 


\section{Conclusion}

A relatively new nautical market may be considered to be the meeting of supply and demand of goods and services in nautical tourism. By implementing an analysis system, two of its essential subsystems are identified, i.e. off-shore and on-shore technical-technological subsystems. An off-shore subsystem in nautical market relates to the technical-technological systems on the water and/or land in the function of nautical tourism. An on-shore system in the nautical market relates to all the technical-technological systems on land in the function of the nautical market and in this manner includes nautical tourism ports and the surroundings. In the continued development of nautical tourism, the essential processes are expressed as guidelines with respect to maritime safety, education, protection, impact on the environment and optimal management.

\section{References}

[1] http://en.wikipedia.org/wiki/Nautical_tourism

[2] http://www.pfst.hr

[3] http://www.hhi.hr

[4] http://www.nmma.org

[5] Kasum, J., Marusic, E., Grzetic, Z., Security of non convention ships and nautical tourism ports, TIEMS conference, Seoul, 2006.

[6] Kasum, J., Grzetic, Z., Marusic, E., Contribution to the development of management and strategic decision making in nautical tourism ports, Promet-Traffic-Transportation, Zagreb, 2007.

[7] Kasum, J., Vidan, P., Grzetic, Z., Security and nautical tourism ports, International Conference on Protection and Safety of the Adriatic Sea, Book of Proceedings, RCADR, Split, 2008.

[8] Kasum, J., Bozic, Fredotovic, K., Vidan, P., How nautical tourism ports affect the environment, Management of Natural Resources, Sustainable Development and Ecological Hazards II, Brebbia, C.A.; Jovanovic, N.; Tiezzi, E., Wessex, WIT press, 2009.

[9] Kasum, J., Ivancic, P., Stanivuk, T., Maritime accidents and activities of international community, GIS Odyssey 2010 Proceedings: Space, Heritage \& Future, Zagreb, HIZ GIS Forum, Croatia, University of Silesia, Poland, 2010 . 